\title{
O Suicidante do Moraleda
}

TRADUZIDO POR MARA GONZALEZ BEZERRA \& MARY ANNE WARKEN SOARES SOBOTTKA 


\section{EL SUICIDANTE DEL MORALEDA}

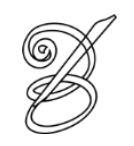

\section{Aldo ASTETE CUADRA ${ }^{1}$ \\ Chile}

Traduzido por:

Mara Gonzalez BEZERRA ${ }^{2}$

Universidade Federal de Santa Catarina

Mary Anne Warken Soares SOBOTTKA
Universidade Federal de Santa Catarina

Figura 1. Ilustração El suicidante del Moraleda

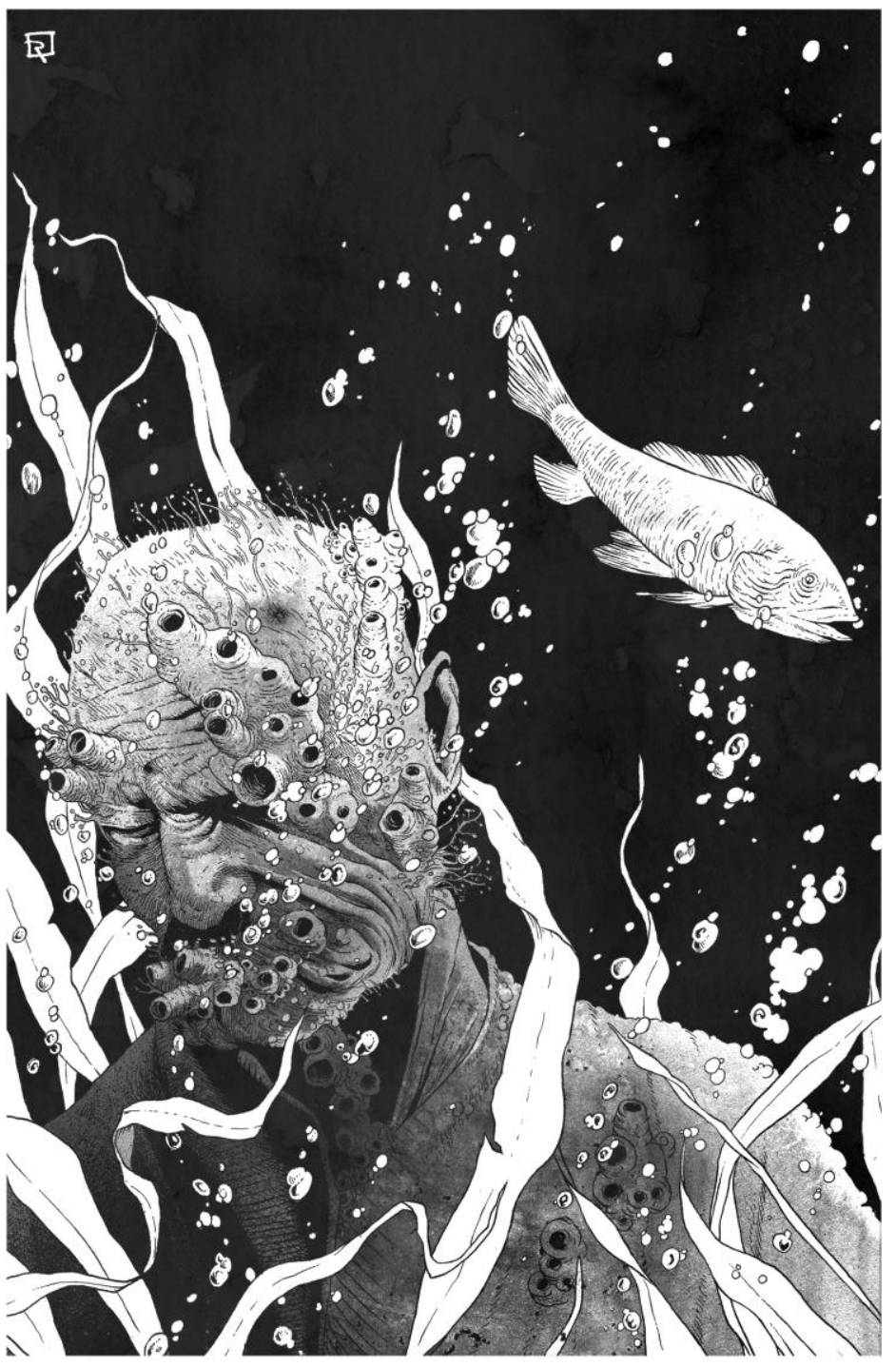




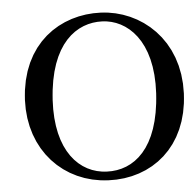

conto O Suicidante do Moraleda ${ }^{4}$ traduzido da língua espanhola, na variante chilena, para a língua portuguesa, do escritor Aldo Astete Cuadra (1978) cujo título original é El suicidante del Moraleda, foi publicado pela Austrobórea em 2017 na coletânea Chile de Terror. O autor é professor e mestre em Literatura Hispano-americana. A sua concepção do terror tem origem no resgate das lendas narradas pelos moradores da região do sul do Chile. A partir desses temas autóctones desenvolveu a sua narrativa povoada de mitos, tradições próprias do Chile, e recontados de forma que sugira o medo, o irreal e a angústia. Ao escrever habitualmente textos cuja tônica é o horror, Aldo desenvolveu uma variação do gênero ao qual denominou Terror Lárico ${ }^{5}$. Ele também é o editor e diagramador das editoras Austrobórea Editores e Sur Umbral Ediciones. A edição em que este conto está inserido foi totalmente dedicada ao terror, e é distribuída principalmente nos países de fala hispana. Ela foi organizada por Paulo Lehmann (1976-), escritor e jornalista chileno, e conta com um posfácio assinado pelo poeta Thomas Harris (1956-).

Sobre o projeto idealizado para esta tradução, se fará um breve comentário. A narrativa propicia o efeito de suspense a que se propõe o autor a partir da inserção de elementos reais e sobrenaturais no texto. O conto traduzido é um vislumbre dos mitos e histórias do imaginário chileno, e tomamos as palavras de Thomas Harris 6 para descrever "hay un horror lovecraftiano lárico, situado en el confín del mito, es sur, pero que a la vez, nos habla de situaciones contingentes que sufren los habitantes del sur, con sus mitos, sus ritos, sus horrores y sus deseos". Este viés é mantido durante a tradução, o que permite ao leitor múltiplos pontos de vista sobre o fim do conto.

Um rápido comentário a respeito da tradução será sobre as escolhas lexicais envolvendo as palavras verdá e usté, ambas recriam a oralidade do discurso na própria língua espanhola desenvolvida em um dos diálogos. Os rasgos sociolinguísticos estão presentes e são respeitados na tradução no que se refere ao diálogo entre os personagens. Cabe salientar que optamos pelo uso literal de verdá porque remete o significado para o leitor, e para usté, usamos cêe, porque demonstra que o personagem reproduziu uma marca da oralidade. A tradução do título foi também um momento de pesquisa e reflexão, e optamos em manter o léxico suicidante, uma vez que tem o mesmo entendimento lexical na língua de chegada. O título é importante porque não foi colocado em uma posição de adaptação, mas antecipa elementos importantes para o leitor inferir um suspense anunciado e ao mesmo tempo uma apresentação e motivação que fazem parte do gênero terror desenvolvido pelo escritor. Desejamos a você uma boa leitura! 


\title{
O SUICIDANTE DO MORALEDA
}

\author{
EL SUICIDANTE DEL MORALEDA ${ }^{7}$
}

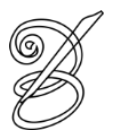

Autor:

Aldo Astete Cuadra

Traduzido por:

Mara Gonzalez BEZERRA

Universidade Federal de Santa Catarina

Mary Anne Warken Soares SOBOTTKA

Universidade Federal de Santa Catarina

\begin{tabular}{|l|}
\hline EL SUICIDANTE DEL MORALEDA \\
\hline Elías llevaba horas navegando entre los \\
canales australes y desde el techo de la \\
barcaza, disfrutaba de un paisaje \\
esplendoroso junto a una decena de \\
personas, que indicaban extasiadas hacia \\
algún cerro cortado a pique, o ante la
\end{tabular}
aparición de algún lobo de mar que acompañaba por tramos a «La Pincoya», con rumbo hacia Puerto Chacabuco.

Al atardecer, se encontraron cerca de una pequeña caleta de pescadores. La temperatura declinó abruptamente, provocando que los curiosos turistas ingresaran a la comodidad de sus butacas. Elías se sentó, esperando que las personas se durmieran pronto. Finalmente, decidió salir, pues aún restaban un par de horas para llegar a Puerto Aguirre y luego de aquel

\section{O SUICIDANTE DO MORALEDA}

Elias já estava navegando por horas entre os canais austrais e do teto da barcaça, apreciava paisagem exuberante compartilhando essa com uma dezena de pessoas que apontavam, extasiadas para algum morro escarpado, ou para algum lobo do mar que surgia e acompanhava por trechos a La Pincoya, cujo destino era Puerto Chacabuco.

Ao entardecer, estavam próximos de uma pequena vila de pescadores. A temperatura caiu abruptamente, fazendo os turistas curiosos retornarem ao conforto dos seus assentos. Elias sentou-se, esperando que as pessoas dormissem logo. Finalmente, decidiu sair, pois ainda faltavam algumas horas para chegar a Puerto Aguirre e depois de lá ainda teria tempo para dormir como os outros, mas antes era necessário conectar-se com o seu eu 


\begin{tabular}{|c|c|}
\hline 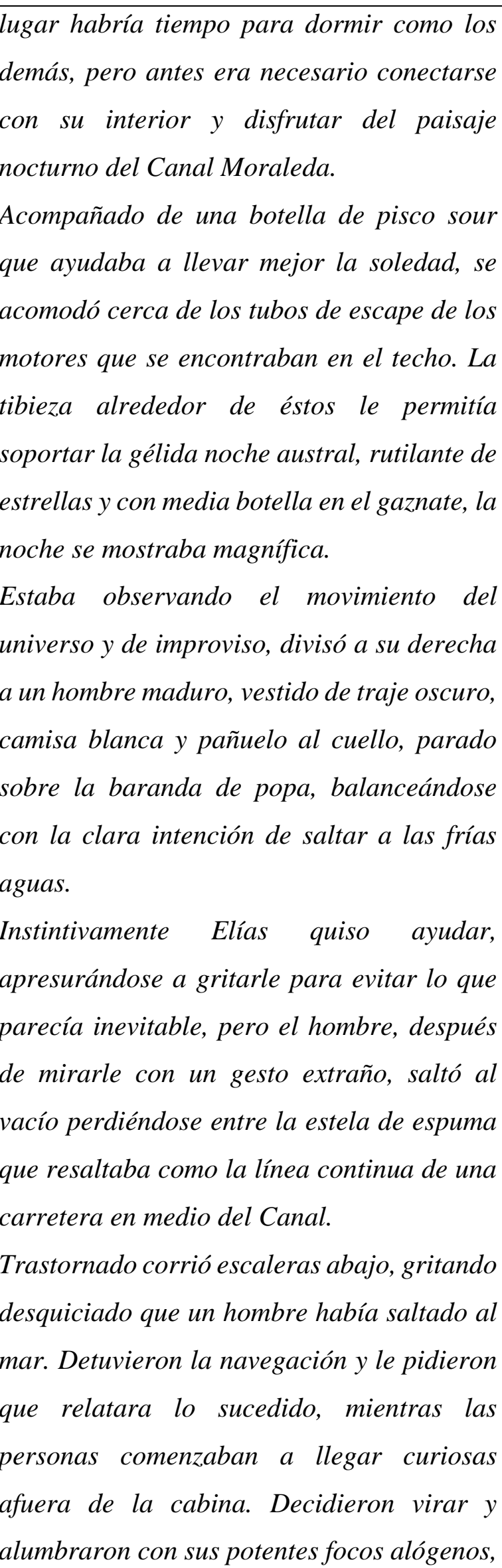 & $\begin{array}{l}\text { Estava observando o movimento do universo } \\
\text { quando, de repente, percebeu à sua direita um } \\
\text { homem maduro, vestido de terno escuro, } \\
\text { camisa branca e um lenço no pescoço, parado } \\
\text { na borda da varanda de popa, que se } \\
\text { balançava com a inequívoca intenção de } \\
\text { saltar nas frias águas. } \\
\text { Instintivamente, Elias quis ajudar, apressou- } \\
\text { se a gritar para o homem e assim evitar o que } \\
\text { parecia inevitável, mas ele, depois de dirigir- } \\
\text { lhe o olhar e com um gesto estranho, saltou } \\
\text { ao vazio perdendo-se no meio de um rastro } \\
\text { de espuma que aparecia como a linha } \\
\text { contínua de uma rodovia no meio do Canal. } \\
\text { Transtornado, correu escada abaixo, gritando } \\
\text { loucamente que um homem tinha pulado no } \\
\text { mar. Pararam a navegação e pediram que } \\
\text { relatasse o acontecido, enquanto as pessoas } \\
\text { começavam a chegar curiosas fora da cabine. } \\
\text { Decidiram retornar e iluminaram com seus } \\
\text { potentes faróis halógenos, rastrearam a } \\
\text { superfície das águas em busca do corpo do }\end{array}$ \\
\hline
\end{tabular}


rastreando la superficie de las aguas en busca del cuerpo del suicida. Mientras tanto, unos tripulantes se encargaban de pasar revista a la tripulación y pasajeros.

El capitán miraba con desconfianza creciente a Elías al percatarse que éste despedía un fuerte hálito alcohólico. Sin embargo, la sospecha se transformó en convicción cuando determinaron que no había personas faltantes en «La Pincoya», tripulación y pasajeros se encontraban presentes.

— ¡Borracho imbécil, estás alucinando, vete a dormir! - le increpó una mujer.

- ;Cómo es posible que le crean a este estúpido alcohólico! —exclamó un hombre viejo.

Las recriminaciones se multiplicaron y Elías comenzó a verse en problemas, pero estaba seguro de haber visto a un hombre saltar a las aguas. Cómo podría guardar silencio ante tal hecho, su deber era comunicar la emergencia, las consecuencias que aquel acto le acarrearían eran harina de otro costal, eso le entregaba algo de serenidad ante un ambiente hostil que se comenzaba a encender a su alrededor. Para salvaguardar su integridad, decidieron detenerle en el cuarto de máquinas, mas no intentó resistirse. Buscaba explicaciones convincentes para lo sucedido, y comentaba en voz alta haber visto a un hombre de pelo suicida. Entretanto, alguns tripulantes se encarregaram da contagem da tripulação e dos passageiros.

O capitão olhava com desconfiança cada vez maior para Elias ao perceber que ele expelia um forte bafo de álcool. No entanto, a suspeita se transformou em convicção quando sentenciaram que não faltavam pessoas no La Pincoya, tripulação e passageiros estavam todos a bordo.

- Bêbado idiota, você está alucinando, vai dormir! - vociferou uma mulher.

- Como é possível que acreditem neste bêbado estúpido! - exclamou um homem mais velho.

As recriminações se multiplicaram e Elias percebeu que estava com problemas, mas estava certo de que tinha visto um homem pular na água. Como iria ficar em silêncio diante desse fato? Seu dever era informar a ocorrência, e as consequências geradas por conta daquela atitude eram farinha de outro saco, e isso era o que o deixava um pouco mais sereno perante o ambiente hostil que começava a desenhar-se ao seu redor. Para salvaguardar a sua integridade, decidiram detê-lo na sala das máquinas, mas nem tentou resistir. Buscava explicações convincentes para o acontecido, e comentava em voz alta sobre ter visto um homem de cabelos grisalhos, magro e olhar penetrante. Podia ser algum infiltrado. 
cano, delgado y mirada penetrante. Tal vez se trataba de algún polizonte ${ }^{1}$.

Quizás hayan contado mal -añadía. Pero cada vez los tripulantes le miraban con mayor impaciencia, así es que optó por callar.

Minutos más tarde le comunicaron que por orden del Capitán sería desembarcado en Puerto Aguirre. No podía continuar viajando en la condición de detenido, sus captores argumentaban que devolverlo a la sala de pasajeros era peligroso. Esta vez sí protestó, aunque sin demasiada convicción. Su reproche denotaba resignación, ya no quería saber nada más del asunto. La cabeza le daba vueltas y el cansancio físico y mental estaba haciendo mella en sus certezas.

A media noche la barcaza recaló en Puerto Aguirre, el pueblo parecía precipitado al mar. Esas pequeñas luces filtradas de las ventanas resplandecían ante la inmensidad oscura de un cielo ausente. Pensó bajar en silencio, pasar desapercibido, pero no fue así. Le maldecían desde lo alto, debiendo agachar la cabeza y caminar rápidamente entre los vehículos de cubierta. A su vez, sentía que los pasajeros que iban abordando lo miraban con rabia, intuyendo que la noticia se había comunicado por radio y que todos estaban enterados y furiosos, al tener
Talvez tinham somado errado - dizia. Mas, a cada fala, os tripulantes o olhavam mais impacientes, então preferiu ficar calado.

Minutos depois foi comunicado que seria desembarcado em Puerto Aguirre por ordem do Capitão. Não podia continuar viajando como detido, e seus captores argumentavam que devolvê-lo para a sala dos passageiros era perigoso. Desta vez, sim, protestou, mas sem muita convicção. Seu protesto denotava resignação, já não queria saber mais nada do assunto. A cabeça rodava e o cansaço físico e mental esburacavam suas certezas.

À meia-noite, a barcaça chegou a Puerto Aguirre, a vila parecia jogada ao mar. As pequenas luzes filtradas pelas janelas resplandeciam diante da imensidão escura de um céu ausente. Quis descer em silêncio, passar despercebido, mas não foi assim. $\mathrm{O}$ amaldiçoavam desde o alto, tendo que abaixar a cabeça e caminhar rapidamente entre os veículos no convés. Por sua vez, sentia que os passageiros que embarcavam o olhavam com raiva, intuiu que a notícia tinha sido difundida pelo rádio e que todos estavam a par e furiosos, porque tiveram que esperar a barcaça noite adentro, por culpa de um ébrio enlouquecido.

\footnotetext{
${ }^{1}$ N. T.: De acordo com o autor deste conto, Aldo A. Cuadra, esta palavra é de fato polizón, e não polizonte, como figura na edição do texto fonte.
} 
que esperar la barcaza en medio de la noche, por culpa de un ebrio enloquecido.

Intentó salir del muelle lo más rápido que pudo, esquivando a las personas que acarreaban sus equipajes, mientras un camión descendió lentamente por la rampla. Seguro todos tendrían donde quedarse pensó-, y mucho menos me darán hospedaje a mí. Elías no conocía el pueblo, una serie de edificaciones verticales sobre un abrupto cerro, en medio de la oscuridad y el silencio. Esta imagen lo llenaba de desaliento.

«La Alejandrina», otra de las barcazas, no pasaría sino hasta el mediodía por lo tanto debía esperar en algún sitio. Las nubes y un viento frío iniciaban su desenfreno, una tormenta estaba próxima. No debió pensar mucho sobre qué hacer para resguardarse, ya que luego de iniciar su vagabundeo por el pueblo, a unas cuantas casas del muelle, un pequeño letrero en el que se leía «BarRestorán Don Fausto» le devolvieron el alma al cuerpo. Ingresó por una gran puerta de madera, tallada con imágenes de naufragios y sirenas. En su interior, lámparas a kerosene emitían una luz danzante, movediza, que le daba un aspecto mágico al lugar. Sin embargo, no sintió la temperatura agradable que imaginó encontrar al interior de la edificación, y una ráfaga de aire marino le caló los huesos como lo hacen los malos presentimientos. Aún estaba reponiéndose de su decepción cuando un ladrido bronco lo
Tentou sair do cais o mais rápido que podia, esquivando às pessoas que carregavam suas bagagens, enquanto um caminhão desceu lentamente pela rampa. Certamente todos teriam onde ficar - pensou - e com certeza não darão hospedagem logo a mim. Elias não conhecia a vila, uma série de edificações verticais sobre um morro escarpado, no meio da escuridão e do silêncio. Esta imagem o enchia de desalento.

La Alejandrina, outra das barcaças, não passaria por ali se não até meio dia, portanto devia esperar em algum lugar. As nuvens e um vento frio iniciavam seu desvario, uma tormenta se aproximava. Não precisou pensar muito sobre o que fazer para proteger-se, porque ao iniciar seu vagabundeio pela vila, logo a uma pouca distância do cais, um pequeno letreiro indicava Bar-Restorán Don Fausto e isso o reconfortou. Entrou pela enorme porta de madeira toda entalhada com imagens de naufrágios e sereias. No interior, luminárias de querosene emitiam uma luz bruxuleante, tremulante, que dava um aspecto mágico ao lugar. No entanto, não sentiu a temperatura agradável como imaginava encontrar no interior da edificação, e uma rajada de ar marinho penetrou até seus ossos tal como fazem os maus pressentimentos. Ainda estava se recompondo da sua decepção quando um latido grave o desconcertou, afogando um grito de espanto. Três homens encontravam- 


\begin{tabular}{|c|c|}
\hline $\begin{array}{l}\text { descolocó, ahogando un grito de espanto. } \\
\text { Tres hombres se encontraban en el mesón del } \\
\text { bar, quienes al observar la situación no } \\
\text { pudieron evitar reírse de manera burlesca. El } \\
\text { perro San Bernardo luego del ladrido, } \\
\text { retornó a un profundo sueño. } \\
\text {-Buenas noches amigo, ¿qué lo trae por } \\
\text { aquí a estas horas? } \\
\text {-Estoy en busca de alojamiento - respondió } \\
\text { secamente Elías cansado de las burlas y los } \\
\text { malos tratos. } \\
\text {-Ha llegado al lugar adecuado, pero antes } \\
\text { acompánenos con una cañita de vino. } \\
\text { Imagino que no tendrá sueño - habló el } \\
\text { contertulios. } \\
\text { cantinero. }\end{array}$ & 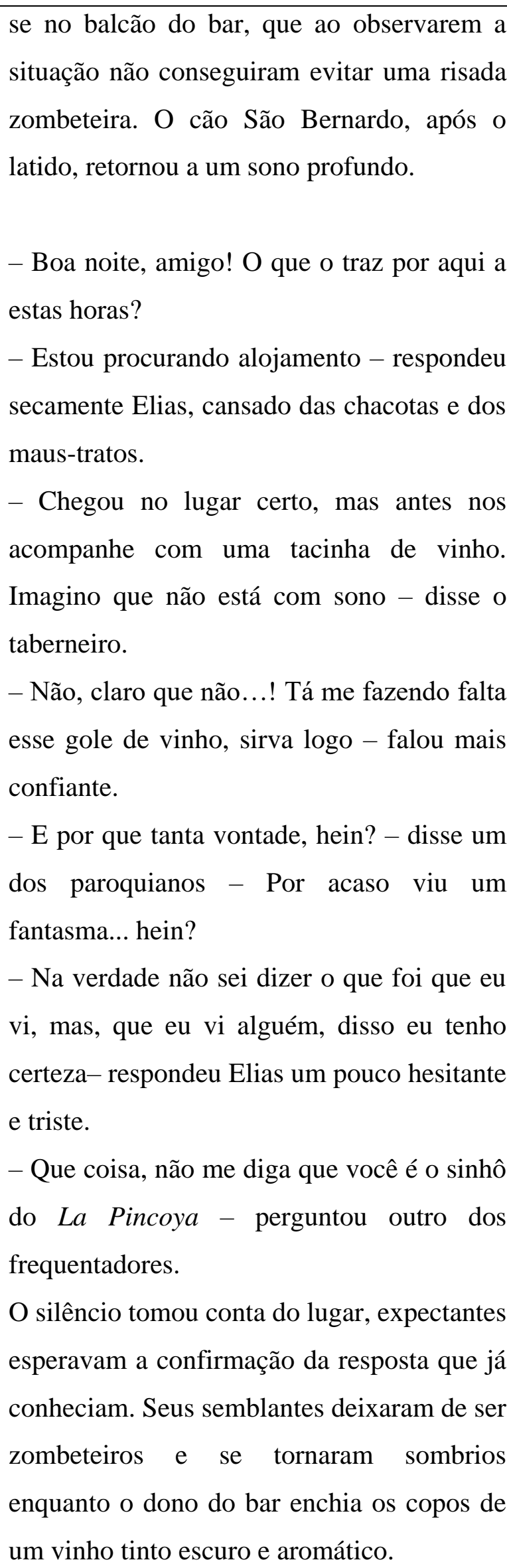 \\
\hline
\end{tabular}




mientras el cantinero rellenaba los vasos de
un vino tinto oscuro y aromático.
- Sí... pero estoy seguro de haberlo visto
saltar, estaba como a seis metros de mí. -y
continuó con la descripción que hiciera ya
tantas veces.

Los tres hombres lo miraron con un dejo de compasión.

- Seguramente ustedes tampoco me creerán, seguro piensan que estoy loco o que estaba demasiado borracho, pero se los reitero, ese hombre saltó al vacío, lo vi nítidamente brincar y perderse en la espuma. Los hombres se miraron entre sí con complicidad.

— ¿Me creen verdad? Ustedes saben de lo que hablo.

-Mire, la verdá es que no nos sorprende. Los antiguos dicen que en el Canal se puede ver, en ciertas épocas del año, a un Suicidante... seguro que usté vio a uno de esos. Los mayores culpaban a los Suicidantes de los accidentes en el Canal y...

— ¿Cómo accidentes?

-Sí, de las personas que se han arrojado al agua para intentar salvar al Suicidante. La mayoría no regresa, sus cuerpos desaparecen, se los traga el Moraleda.

- ¿Y por qué nadie me dijo esto, por qué todos me creyeron loco?

-Son muy pocos los que creen en estas cosas, algunos se rien de los creyentes...
- Sim..., mas estou certo de ter visto alguém pular, estava mais ou menos seis metros de distância de mim. - E seguiu com a mesma descrição que já fizera tantas vezes.

Os três homens olharam para ele com um ar de compaixão.

- Certamente vocês também não acreditarão, e com certeza pensam que estou louco ou que estava muito bêbado, mas reafirmo, esse homem saltou no vazio, pude ver claramente pular e se perder na espuma. Os homens se olharam com cumplicidade.

- Acreditam em mim, não é? Vocês sabem do que estou falando.

- Olhe, a verdá é que não nos surpreende. Os antigos dizem que no Canal dá pra ver, em algumas épocas do ano, um Suicidante... certamente $c \hat{e}$ viu um desses. Os mais velhos culpavam os Suicidantes pelos acidentes acontecidos no Canal e...

- Acidentes? Como assim?

- Sim, das pessoas que se jogaram na água para tentar salvar o Suicidante. A maioria não volta, seus corpos desaparecem, e são engolidos pelo Moraleda.

- E por que ninguém me falou isso? Por que todos pensaram que eu estava louco?

- São muito poucos os que acreditam nestas coisas, alguns riem dos crédulos... dizem que as pessoas se matam porque não querem viver, e o resto é pura mentira. Invenções para 


\begin{tabular}{|c|c|}
\hline 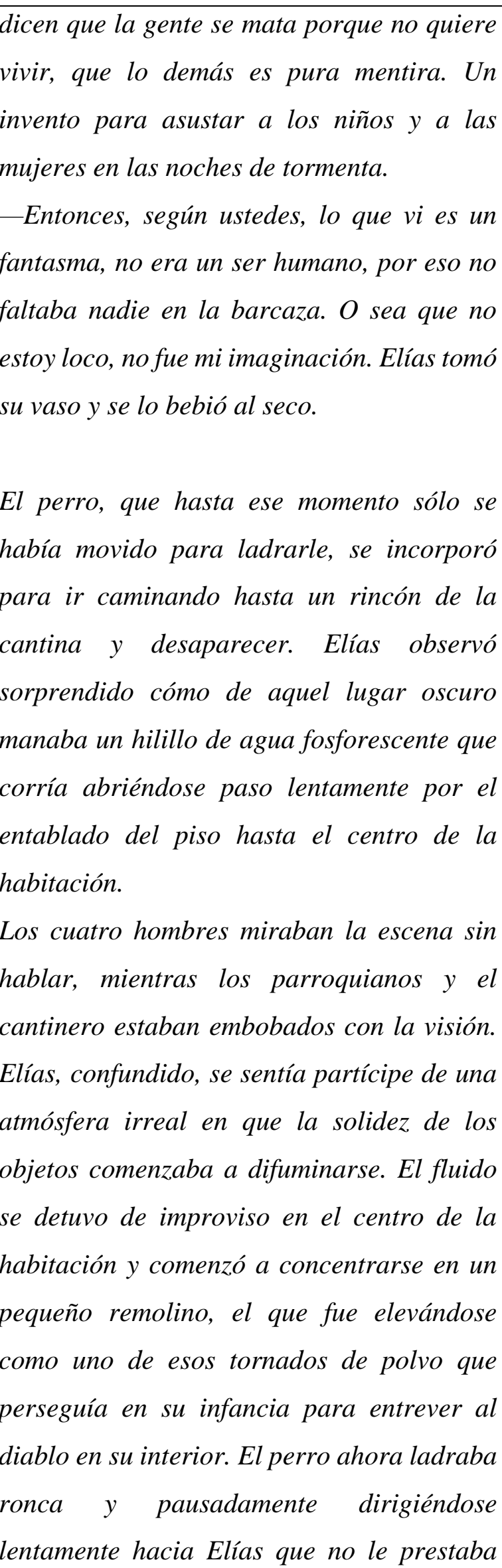 & $\begin{array}{l}\text { assustar crianças e mulheres nas noites de } \\
\text { tormenta. } \\
\text { - Então, de acordo com vocês, o que eu vi é } \\
\text { um fantasma, não era um ser humano, por } \\
\text { isso não faltava ninguém na barcaça. Ou seja, } \\
\text { não estou louco e não foi minha imaginação. } \\
\text { Elias pegou seu copo e tragou em seco. } \\
\text { O cachorro, que até esse momento tinha se } \\
\text { movido apenas com o fim de latir para ele, } \\
\text { levantou-se e andou até um canto da cantina } \\
\text { e desapareceu. Elias observou surpreso como } \\
\text { daquele lugar escuro manava um fiozinho de } \\
\text { água fosforescente que fluía lentamente, } \\
\text { abrindo caminho pelas madeiras do piso até o } \\
\text { centro do salão. } \\
\text { Os quatro homens olhavam a cena sem falar, } \\
\text { enquanto os paroquianos e o taberneiro } \\
\text { estavam estupefatos com a visão. Elias, } \\
\text { confuso, se sentia partícipe de uma atmosfera } \\
\text { irreal em que a solidez dos objetos começava } \\
\text { a esfumar-se. O fluído se deteve de repente } \\
\text { no centro do salão e começou a transformar- } \\
\text { se em um pequeno redemoinho, elevando-se } \\
\text { igual a um daqueles tornados de poeira que } \\
\text { perseguia em sua infância para entreolhar o } \\
\text { diabo no seu interior. Agora, o cão latia rouco } \\
\text { e pausadamente, dirigindo-se lentamente até } \\
\text { manão de uma forma humanoide. }\end{array}$ \\
\hline
\end{tabular}




\begin{tabular}{|c|c|}
\hline 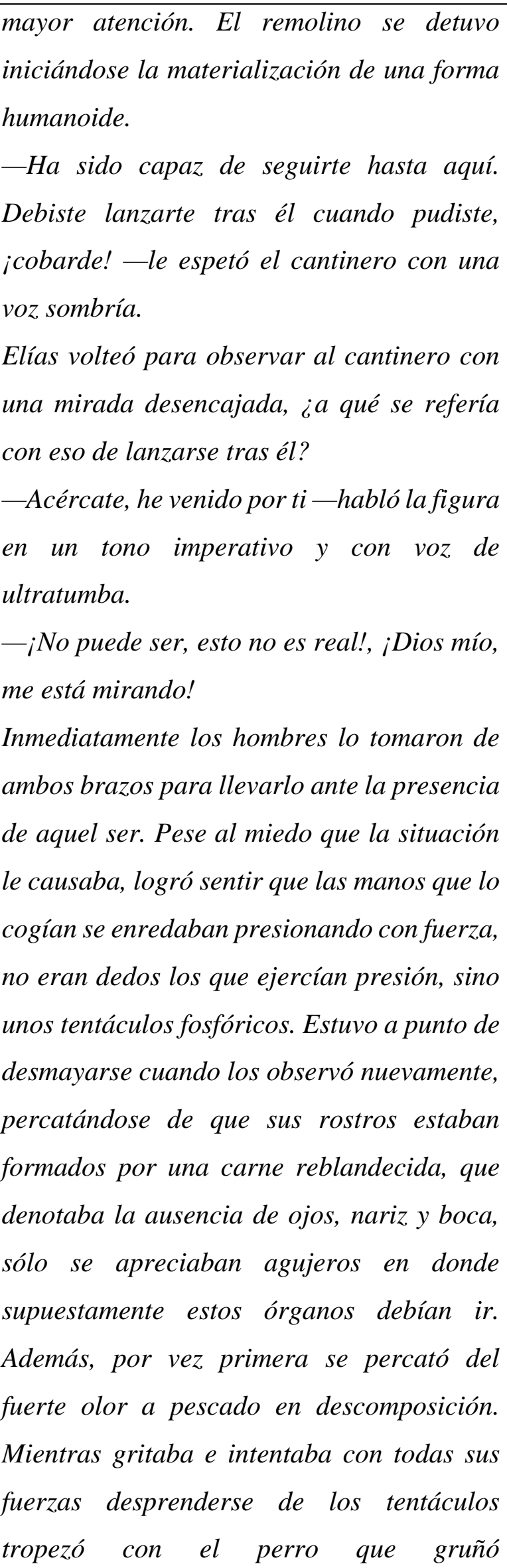 & $\begin{array}{l}\text { - Foi capaz de te seguir até aqui. Você devia } \\
\text { ter se lançado atrás dele quando podias, } \\
\text { covarde! - alfinetou o cantineiro com uma } \\
\text { voz sombria. } \\
\text { Elias virou-se para observar o dono do bar } \\
\text { com um olhar perplexo. A que se referia com } \\
\text { isso de se atirar logo atrás dele? } \\
\text { - Aproxime-se, vim te buscar - falou a figura } \\
\text { em um tom imperativo e com voz sepulcral. } \\
\text { - Não pode ser, isto não é real! Meu Deus, tá } \\
\text { me olhando! } \\
\text { Imediatamente os homens o tomaram pelos } \\
\text { braços para levá-lo diante daquele ser. } \\
\text { Apesar do medo que a situação provocava } \\
\text { nele, conseguiu sentir que as mãos que o } \\
\text { seguravam se entrelaçavam pressionando } \\
\text { com força, e não eram os dedos que exerciam } \\
\text { pressão, mas uns tentáculos fosfóricos. Quase } \\
\text { desmaiou quando os observou novamente, } \\
\text { entendendo que os rostos eram feitos de uma } \\
\text { carne flácida, que evidenciava ausência de } \\
\text { olhos, nariz e boca, e só se notavam buracos } \\
\text { onde supostamente esses órgãos deveriam } \\
\text { estar. Além disso, pela primeira vez se deu } \\
\text { conta do forte cheiro a peixe em } \\
\text { decomposição. Enquanto gritava e tentava } \\
\text { com todas suas forças desvencilhar-se dos } \\
\text { agora ena ton topeçou no cão que rosnou }\end{array}$ \\
\hline
\end{tabular}


agresivamente, pero ya no era igual, ahora era un lobo marino inmenso de pelaje dorado que se deslizaba sobre su cuerpo impulsado con sus aletas. De pronto, se encontró bajo un muelle, con las olas rompiendo en los pilares, las algas acumulándose a su alrededor, pudiendo sentir la frialdad del agua salada. El sonido del mar llenábale los oídos. Pese a lo demencial de los sucesos que estaba viviendo, Elías, resignado, se sometió a sus captores. Entendía vagamente que no sería posible escapar de lo que seguramente era su destino. Las palabras «he venido por ti» resonaban en su interior como un mandato imposible de contradecir.

El Suicidante se acercó y comenzó a disolverse en una especie de espuma seminal que ingresó por sus orificios nasales, por su garganta, los oídos, el ano.

Esta substancia invadía su interior repletándolo de sal. Sus ojos estallaron y de ellos brotó sangre en forma de coágulos que inmediatamente fue consumida por cangrejos y langostas que habían acudido a darse un festín con las entrañas que se precipitaron de su boca y recto. El cuerpo deforme se hincharía hasta explotar. Todo esto Elías lo sentía desgarradoramente, el dolor le mantenía vivo, una sensación de ardor interno, una ebullición visceral que lo llevaba a los límites de la muerte.

Más tarde comprendería que se había saltado la muerte, que su transformación era trapiche, com as ondas quebrando contra os pilares, as algas acumulando-se ao seu redor, podendo sentir o frio da água salgada. $\mathrm{O}$ som do mar enchia seus ouvidos. Apesar da insanidade dos acontecimentos que vivenciava, Elias, resignado, submeteu-se aos seus sequestradores. Entendia vagamente que não seria possível escapar do que certamente era seu destino. As palavras "vim te buscar" ecoavam no seu interior como um mandato impossível de contradizer.

O Suicidante se aproximou e começou a dissolver-se em uma espécie de espuma seminal que entrou pelos seus orifícios nasais, por sua garganta, os ouvidos, o ânus.

A substância invadia seu interior e o inundou de sal. Seus olhos explodiram e deles brotaram coágulos de sangue imediatamente consumidos por caranguejos e lagostas que tinham vindo para fazer um festim com as entranhas jorradas pela boca e o reto. O corpo disforme iria inchar até explodir. Tudo isto Elias sentia descarnando-se, a dor o mantinha vivo, uma sensação de ardência interna, uma ebulição visceral que o levava aos limites da morte.

Mais tarde, ele compreenderia que tinha driblado a morte, e que sua transformação era a passagem de um estado a outro. Enquanto boiava junto ao sargaço, arrastado pelas correntes em direção ao Moraleda, e o seu simulacro de corpo servia de habitat para crustáceos, se perguntava que sentido tinha 


\begin{tabular}{|l|l|}
\hline el paso de un estado a otro. Mientras flotaba & tudo isto ou no que tinha se transformado. \\
junto al sargazo arrastrado por las & Como o fato de ter visto por acaso o \\
corrientes en dirección del Moraleda, y su & Suicidante o tinha levado a esta situação \\
remedo de cuerpo servía de hábitat para & tenebrosa? Pensava que isto era o que \\
crustáceos, se preguntaba qué sentido tenía & chamam de inferno na terra, mas, que tinha \\
todo esto o en qué se había convertido. Cómo & feito para merecê-lo? E, no que tinha se \\
el haber observado accidentalmente al & transformado? Qual era seu papel? O certo é \\
Suicidante le había llevado a esta situación & que jamais teria a real consciência do seu \\
desesperada. Pensaba que esto debía ser lo & estado, pelo menos, não o que nós, seres \\
que llaman infierno en la tierra, pero qué & humanos, conhecemos por consciência. \\
había hecho para merecerlo. Pero en ¿qué se & \\
había convertido, ¿cuál era su función? Lo & \\
cierto es que jamás tendría real consciencia & \\
de su estado, no al menos lo que nosotros, los & \\
seres humanos, conocemos por consciencia. &
\end{tabular}

\footnotetext{
${ }^{1}$ Aldo Astete Cuadra. Escritor chileno. Mestre em Literatura hispano-americana contemporânea pela Universidad Austral de Chile.

2 Mara Gonzalez BEZERRA - Doutora em Estudos da Tradução (2016) pela Universidade Federal de Santa Catarina. Mestre em Literatura (2011) e Licenciada em Língua e Literatura Espanhola (2008) pela mesma universidade. Bacharel em Educação Religiosa (1989) pelo Instituto Batista de Educação Religiosa. Atualmente realiza estágio pós-doutoral (2017) na Pós-graduação em Estudos da Tradução na Universidade Federal de Santa Catarina. Florianópolis, Santa Catarina, Brasil. Lattes: http://lattes.cnpq.br/0696362088302744 ORCID: https://orcid.org/0000-0001-8390-5910 E-mail: mara.gonzalez.letras@ gmail.com
}

3 Mary Anne Warken Soares SOBOTTKA - Doutoranda e Mestre (2017) em Estudos da Tradução pela Universidade Federal de Santa Catarina. Graduada em Língua e Literatura Espanhola (2014) pela mesma universidade. Florianópolis, Santa Catarina, Brasil. Lattes: http://lattes.cnpq.br/7707356833300677 ORCID: https://orcid.org/0000-0003-4448-525X E-mail: warkenespanholufsc@gmail.com

\footnotetext{
${ }^{4}$ N. T.: A tradução deste conto foi autorizada, via e-mail, pelo escritor Aldo Astete Cuadra, ao qual agradecemos imensamente a gentileza pela autorização de traduzir e publicar o conto em questão. Agradecemos também ao ilustrador Fabián Rivas Belmar por ter nos autorizado, por e-mail, utilizar a ilustração publicada com o conto.

${ }^{5}$ A definição de terror lárico a seguir foi transcrita exatamente como o autor respondeu ao ser perguntado sobre o que seria a definição do gênero: "se inmiscuye en lo cotidiano de la FRONTERA, de ese espacio pueblerino en el que la tradición vista como un recuerdo imposible de traer al presente gatilla en el lector la memoria de la infancia en un espacio bucólico, en el centro de la edad de oro. No confundir con el relato costumbrista, sino que, con el fantástico gótico, pero, en vez de castillos y mansiones, lo situamos en el descampado y en lo rural, en lo eriazo y lo atemporal".
} 
${ }^{6}$ HARRIS, Thomas. Contracapa.In: CUADRA, Aldo Astete. El Suicidante del Moraleda. In: Chile del Terror III, Mare Monstrum. Paulo Lehman (orgs). Valdívia: Austrobórea Editores, 2017. Saiba mais sobre Thomas Harris. Disponível em: <https://goo.gl/qgLQ8h>. Acesso em 05 jun 2018.

${ }^{7}$ N.de.T.: A tradução deste conto foi autorizada, via e-mail, pelo autor, Prof. Aldo Andrés Astete Cuadra, em março de 2018. Agradecemos a gentileza pela autorização para que pudéssemos traduzir e publicar o conto referenciado. CUADRA, Aldo Astete. El Suicidante del Moraleda. In: Chile del Terror III, Mare Monstrum. Paulo Lehman (orgs). Valdívia: Austrobórea Editores, 2017. Disponível em: <http://chiledelterror.blogspot.com.br/2012/10/el-suicidante-del-moraleda-por-aldo.html>. Último acesso em: 10 março 2018. 